\title{
Peningkatan Produktivitas Kerja Karyawan Melalui Semangat Kerja
}

\section{Suatu Penelitian pada Koperasi Warga Makmur Unit Marisa Kabupaten Pohuwato}

\author{
Muliadi \\ Dosen Sekolah Tinggi Islam Ekonomi [STIE] Ichsan Pohuwato \\ imuliadi@yahoo.com
}

\begin{abstract}
Focus of this study is to discuss Employee Productivity Improvement through work spirit. The purpose of this research is to study the impression of the work spirit on increasing employee productivity at the Marisa Unit Prosperous Cooperative in Pohuwato Regency. Research is participatory research, using questionnaires as research instruments and using simple regression analysis. The results showed that the work spirit was positive and significant towards work productivity of 0.569 (56.9\%), while $43.1 \%$ did not discuss the model or not.
\end{abstract}

Keywords: Work spirit, Work productivity and Cooperation.

\section{Pendahuluan}

Manusia sebagai salah satu faktor produksi tidak dapat disamakan dengan faktor-faktor produksi lainnya. Begitu juga manusia yang satu berbeda dengan manusia lainnya. Oleh karena itu pimpinan perusahaan dituntut untuk bisa menciptakan suasana kerja aman dan nyaman 
sehingga semangat kerja karyawan dapat ditingkatkan. Semangat kerja erat kaitannya dengan masalah produktivitas sebab sebenarnya produktivitas kerja merupakan akibat, tetapi juga sekaligus sebab dari suatu proses produksi yang rendah, pendapatan yang rendah, teknologi yang rendah, maupun keterampilan yang rendah. Untuk itu dalam usaha meningkatkan produktivitas perusahaan perlu memperhatika semangat kerja karyawan. Indikasi menurunnya semangat kerja penting untuk diketahui setiap perusahaan karena dengan mengetahui indikasi ini akan dapat diketahui sebab-sebab turunnya semangat kerja. Menurut Nitisemito (1991: 161) indikasi turunnya semangat kerja adalah turunnya produktivitas kerja, tingkat absensi yang tinggi, labour turn over yang tinggi,kerusakan yang tinggi, kegelisahan dimana-mana, tuntutan yang sering tejadi, dan sering terjadinya pemogokan karyawan.

Secara umum produtivitas diartikan sebagai hubungan antara hasil nyata maupun fisik (barang-barang dan jasa), dengan masukan yang sebenarnya atau suatu perbadingan antara hasil keluaran dan masukan (output dan input). Produktivitas juga diartikan sebagai tingkatan efisiensi dalam memproduksi barang-barang dan jasa-jasa. Bisa terjadi produksi meningkat, tetapi produktivitasnya tidak dan bahkan menurun, Karena produksi berkaitan dengan cara pencpaian tingkat produksi tersebut. Keberhasilan setiap organisasi bisnis tidak terkecuali pada Koperasi sangat tergantung dari kemampuan para pengurusnya atau karyawannya. Lebih khusus pada koperasi Warga Makmur sebagai koperasi simpan pinjam, kemajuanya sangat ditentukan dari perkembangan jumlah anggota atau nasaba. Perkembagan jumlah nasabah atau anggota sangat ditentukan dari perang pengurus atau karyawannya.

Dari hasil pengamatan peneliti menunjukkan bahwa produktifitas kerja karyawan atau pengurus pada Koperasi Warga Makmur mengalami penurunan, hal ini ditandai dengan kurang efektifnya dan kurang efisiennya karyawan bekerja yang kemungkinan besar disebakna oleh semangat kerja yang sangat menurun. Permasalahan di atas jika dibiarkan secara terus-menerus sangat berdampak pada pencapaian tujuan organisasi, oleh karena itu manajemen organisasi diharapkan mampu 
menciptakan situasi yang dapat membuat semangat kerja karyawan meningkat yang dimaksudkan agar produktifitas kerja yang lebih baik. Berdasarkan uraian di atas, maka penulis tertarik untuk melakukan penelitiandengan mengangkat judul: Peningkatan Produktivitas Kerja Karyawan Melalui Semangat Kerja (Suatu Penelitian pada Koperasi Warga Makmur Unit Marisa Kabupaten Pohuwato).

Setelah mencermati pemaparan latar belakang di atas, maka yang menjadi inti permasalahan dalam penelitian ini adalah "Bagaimana pengaruh Semangat Kerja terhadap peningkatan Produktivitas Kerja Karyawan Pada Koperasi Warga Makmur Unit Marisa Kabupaten Pohuwato".

\section{Kajian Teori}

\section{Pengertian Semangat Kerja}

Nawawi (1990: 154-155) mengemukakan bahwa semangat kerja akan menyentuh aspek kemauan, kehendak, pikiran dan sikap dalam melaksanakan pekerjaan. Semangat kerja yang tinggi dan positif merupakan faktor yang berpengaruh pada sikap, berupa kesediaan mewujudkan cara atau metode kerja yang berdaya guna dan berhasil guna dalam meningkatkan produktivitas kerja.

Nitisemito (1992) mengemukakan bahwa semangat dan gairah kerja sulit untuk dipisahkan meskipun semangat kerja memiliki pengaruh yang cukup besar terhadap gairah kerja. Dengan meningkatnya semangat dan gairah kerja, maka pekerjaan akan lebih cepat diselesaikan dan semua pengarug buruk dari menurunnya semangat kerja seperti absensi dan selanjutnya akan dapat diperkecil dan selanjutnya menaikkan semangat kerja dan gairah kerja yang berarti diharapkan juga meningkatkan produktivitas karyawan. Semangat kerja dapat diartikan sebagai semcam pernyataan ringkas dari kekuatan-kekuatan psikologis yang beraneka ragam yang menekan sehubungan dengan pekerjaan mereka. Semangat kerja dapat diartikan juga sebagai suatu iklim atau suasana kerja yang terdapat di dalam suatu organisasi yang menunjukkan rasa 
kegairahan di dalam melaksanakan pekerjaan dan mendorong mereka untuk bekerja secara lebih baik dan lebih produktif.

Cara yang ditempuh untuk meningkatkan semangat kerja adalah memberikan kompensasi kepada tenaga kerja dalam porsi yang wajar, tetapi tidak memaksakan kemampuan perusahaan, menciptkaan kondisi kerja yang menggairahkan semua pihak, memperhatikan kebutuhan yang berhubungan dengan spritual tenaga kerja pada saat penyegaran sebagai media pengurangan ketegangan kerja dan memperkokoh rasa setia antara tenaga kerja dan manajemen, penempatan tenaga kerja pada posisi yang tepat, peran tenaga kerja mengembangkan aspirasi mendapatkan tempat yang wajar, dan memperhatikan hari esok para tenaga kerja. Zainun (2001) menyatakan bahwa ada beberapa faktor yang menyebabkan munculnya semangat kerja. Faktor-faktot tersebut antara lain:

a. Hubungan yang harmonis antara pimpinan dengan bawahan terutama antara pimpinan kerja sehari-hari langsung berhubungan dan berhdapan dengan para bawahan.

b. Kepuasan para petugas terhadap tugas dan pekerjaannya karena memperoleh tugas yang disukai sepenuhnya.

c. Terdapat satu suasana dan iklim kerja yang bersahabat dengan anggota organisasi, apabila dengan mereka yang sehari-hari banyak berhubungan dengan pekerjaan.

d. Rasa pemanfaatan bagi tercapainya tujuan organisasi yang juga merupakan tujuan bersama mereka yang harus diwujudkan secara bersama-sama pula.

e. Adanya tingkat kepuasan ekonomis dan kepuasan nilai lainnya yang memadai sebagai imbalan yang dirasakan adil terhadap jerih payah yang telah diberikan kepada organisasi.

f. Adanya ketenangan jiwa, jaminan kepastian serta perlindungan terhadap segala sesuatu yang dapat membahayakan diri pribadi dan karier dalam perjalanan. 
Menurut Nawawi (2003) faktor-faktor yang mempengaruhi tinggi rendahnya semangat kerja adalah:

1) Minat seseorang terhadap pekerjaan yang dilakukan. Seseorang yang berminat dalam pekerjaannya akan dapat meningkatkan semangat kerja.

2) Faktor gaji atau upah tinggi akan meningkatkan semangat kerja seseorang

3) Status sosial pekerjaan. Pekerjaan yang memiliki status sosial yang tinggi dan memberi posisi yang tinggi dapat menjadi faktor penentu meningkatknya semangat kerja.

4) Suasana kerja dan hubungan dalam pekerjaan. Penerimaan dan Penghargaan dapat meningkatkan semangat kerja.

5) Tujuan Pekerjaan. Tujuan yang mulia dapat mendorong semangat kerja seseorang.

Semangat kerja tidak selalu ada dalam diri karyawan. Terkadang semangat kerja dapat menurun. Indikasi-indikasi menurunnya semangat kerja selalu ada dan memang secara umum dapat terjadi. Menurut Nitisemito (2002), indikasi-indikasi tersebut antara lain:

a) Rendahnya produktivitas kerja. Menurunnya produktivitas dapat terjadi karena kemalasan, menunda pekerjaan, dan sebagainya. Bila terjadi penurunan produktivitas, maka hal berarti indikasi dalam organisasi tersebut telah terjadi penurunan semangat kerja.

b) Tingkat absensi yang naik atau tinggi. Pada umumnya, bila semangat kerja menurun, maka karyawan dihinggapi rasa malas untuk bekerja. Apalagi kompensasi atau upah yang diterimanya tidak dikenakan potongan saat mereka tidak masuk bekerja. Dengan demikian dapat menimbulkan penggunaan waktu luang untuk mendapatkan penghasilan yang lebih tinggi, meski hanya untuk sementara.

c) Labour turn over atau tingkat perpindahan karyawan yang tinggi, keluar masuk karyawan yang meningkat terutama kar- 
yawan yang mengalami ketidaksenangan atau kenyamanan saat mereka bekerja, sehingga mereka berminat bahkan memutuskan untuk mencari tempat pekerjaan lain yang lebih sesuai dengan alasan mencari kenyamanan dalam bekerja. Manajer harus waspada tentang gejala-gejala sperti ini.

d) Tingkat kerusakan yang meningkat. Meningkatnya tingkat kerusakan sebenarnya menunjukkan bahwa perhatian dalam pekerjaan berkurang. Selain itu dapat juga terjadi kecerobohan dalam pekerjaan dan sebagainya. Dengan naiknya tingkat kerusakan merupakaan indikasi yang cukup kuat bahwa semangat kerja telah menurun

e) Kegelisahan dimana-mana. Kegelisahan tersebut dapat berbentuk ketidaktenangan dalam bekerja, keuh kesah serta hal-hal lain. Terusiknya kenyamanan karyawan memungkinkan akan berlanjut pada perilaku yang dapat merugikan organisasi itu sendiri.

f) Tuntutan yang sering terjadi. Tuntutan merupakan perwujudan dari ketidakpuasan, dimana pada tahap tertentu akan menimbulkan keberanian untuk mengajukan tuntutan. Organisasi harus mewaspadai tuntutan secara massal dari pihak karyawan.

g) Pemogokan. Pemogokan adalah wujud dari ketidak puasan, kegelisahan dan sebagainya. Jika hal ini terus berlanjut akan berujung ada munculnya tuntutan dan pemogokan. Sebaliknya ada beberapa penyebab rendahnya semangat kerja karyawan. Hal ini terkait dengan kurang diperhatikannya pengatiran kerja mengenai disiplin kerja, kondisi kerja dan kekurangan tenaga kerja yang terampil dan ahli di bidangnya.

Steers et. al (1995) mengemukakan mengapa seseorang tenaga kerja tidak menyukai pekerjaannya sendiri adalah:

$\checkmark$ Pekerjaan yang terpecah-pecah

$\checkmark$ Kerja yang berulang-ulang

$\checkmark$ Terlalu sedikit menggunakan keterampilan 
$\checkmark$ Daun kerja pendek

$\checkmark$ Kerja remeh serta tidak hanya dukungan sosial.

Menurut Nitisemito (1992) ada beberapa cara untuk meningkatkan semangat kerja karyawan. Caranya dapat bersifat materi maupun non materi, seperti:

o Gaji yang sesuai dengan pekerjaan

o Memperhatikan kebutuhan rohani

o Sekal-kali perlu meciptakan suasana kerja yang santai yang dapat mengurangi beban kerja.

o Harga diri karyawan perlu mendapat perhatian

o Tempat kerja karyawan pada posisi yang tepat

o Berikan kesempatan kepada mereka untuk berprestasi

o Perasaan aman menghadapi masa depan perlu diperhatikan

o Usahakan para karyawan memiliki loyalitas dan kepedulian terhadap organisasi

o Sekali-kali karyawan perlu di ajak berunding untuk membahas kepentingan bersama

o Pemberian insentif yang terarah dalam aturan yang jelas

o Fasilitas kerja yang menyenangkan yang dapat membangkitkan gairah kerja.

Menurut Nitisemito (1992), faktor-faktor yang mengukur semangat kerja adalah:

- Absensi. Absensi menunjukkan ketidakhadiran karyawan dalam tugasnya. Hal ini termasuk waktu yang hilang karena sakit, kecelakaan dan pergi meninggalkan pekerjaan karena alasan pribadi tanpa diberi wewenang. Yang tidak diperhitungkan sebagai absensi adalah diberhentikan untuk sementara, tidak ada pekerjaan, cuti yang sah, periode libur dan pemberhentuan kerja.

- Kerja sama. Kerja sama dalam bentuk tindakan korektif seseorang terhadap orang lain. Kerjasama dapat dilhat dari kesediaan 
karyawan untuk bekerja sama dengan rekan kerja atau dengan atasan mereka untuk mencapai tujuan bersama. Selain itu, kerjasama dapat dilihat dari kesediaan untuk saling membantu di antara rekan sekerja sehubungan dengan tugas-tugasnya dan terlihat ke aktifan dalam kegiatan organisasi.

- Kepuasan kerja sebagai keadaan emosional yang menyenangkan atau tidak menyenangkan di mana para karyawan memandang pekerjaan mereka.

\section{Pengertian Produktivitas}

Menurut Suradji dalam Ridwan (2009: 269) produktivitas kerja bukan semata-mata ditujukan untuk mendapatkan hasil kerja sebanyak-banyaknya, melainkan kualitas kinerjanya juga penting diperhatikan. Oleh karena itu, kinerja organisasi dalam suatu lembaga sangat penting dalam meningkatkan produktivitas kerja. Menurut Whitmore (1979) dalam Sedarmayanti, (2001:58) mengemukakan produktivitas sebagai suatu ukuran atas penggunaan sumber daya dalam suatu organisasi yang biasanya dinyatakan sebagai rasio dari keluaran yang dicapai dengan sumber daya yang digunakan.

Produktivitas hakekatnya mengandung pengertian perbandingan antara hasil yang dicapai (output) dengan keseluruhan sumber daya yang digunakan (input, Input, ialah semua sumber (resources), yaitu sarana dan prasarana yang digunakan dalam proses produksi barang atau jasa. Sarana atau sumber-sumber yang digunakan, misalnya: tenaga kerja (I), biaya (money), peralatan atau mesin (machine), cara kerja (method), pemasaran atau pelayanan (market atau service), termasuk dalam hal ini ialah waktu (time). Di samping itu juga penggunaan daripada prasarana misalnya: gedung, dan alat transport. Yang dimaksud dengan output ialah hasil produksi yang berwujud barang atau jasa.

Hal yang sama dikemukakan pula oleh Sedarmayanti (2001:58) bahwa: Produktivitas memiliki dua dimensi, yaitu efektifitas dan efisiensi. Dimensi efektifitas berkaitan dengan pencapain hasil kerja yang 
maksimal, dalam arti pencapaian target yang berkaitan dengan kualitas, kuantitas dan waktu. Sedangkan dimensi efisiensi berkaitan dengan upaya membandingkan masukan dengan realisasi penggunaanya atau bagaimana pekerjaan tersebut dilaksanakan.

Menurut Wibowo (2008:242) produktivitas sering diukur dalam bentuk masukan dan keluaran ekonomi. Akan tetapi, masukan dan keluaran sumber daya manusia dan sosial juga merupakan faktor penting. Jika perilaku organisasi lebih baik, dapat memperbaiki kepuasan kerja sehingga terjadi peningkatan hasil sumber daya manusia. Produktivitas suatu kegiatan dikatakan meningkat apabila pengembangan program memberikan hasil tambahan sebagai produk sampingan. Misalnya penataan ruang pemukiman, di samping dapat menambah jumlah rumah yang dapat dibangun, tersedia fasilitas sosial yang memungkinkan warga perumahan melakukan interaksi sosial sehingga terjadi hasil sosial yang lebih baik.

Vincent Ohmachanu dan Jose Ross dalam Wibowo (2008: 243) menyatakan bahwa perbaikan harus difokuskan pada teknologi dan peralatan kapital untuk menekan, masukan biaya tenaga kerja sambil menggunakan teknik engineering industri untuk memperbaiki keluaran.

Produktivitas pada prinsipnya tidak terlepas dari perilaku dari orang-orang/karyawan yang terlibat dalam aktivitas kerja pada suatu organisasi. Aktivitas yang dilakukan harus benar-benar memenuhi kualifikasi pekerjaan yang produktif. Kualifikasi pekerjaan yang produktif itu terletak pada karakteristik atau profil karyawan (pegawai) yang produktif.

Sutisnawidjaja (2000: 34) mengemukakan bahwa Produktivitas sektor jasa memang sulit diukur, namun dengan berpedoman pada pendekatan system proses yaitu membandingkan antara input yang dipergunakan dengan output yang dihasilkan kiranya akan dapat memberikan gambaran peningkatan produktivitas kerja”. Lebih lanjut dikatakan bahwa produktivitas kerja pegawai adalah suatu sikap mental yang selalu mempunyai pandangan bahwa mutu kehidupan hari ini harus lebih baik dari kemarin, dan hari esok lebih baik dari 
hari ini. Mengacu pada beberapa pengertian produktivitas kerja di atas, maka konsep produktivitas kerja dalam permasalahan ini dapat diartikan sebagai hasil kegiatan kerja yang dilakukan oleh pegawai baik secara individu maupun kelompok terhadap pelaksanaan tugas yang menjadi beban tugasnya, waktu yang disediakan, kualitas pelayanan yang diberikan, serta tercapainya sasaran/target. Unsur manusia dalam hal ini memegang peranan yang sangat penting.

Faktor-faktor penentu produktivitas tenaga kerja tersebut juga harus ditopang oleh individu yang produktif pula. Menurut Sedarmayanti (2000) yang mengutip pendapat Erich dan Gilmore, ciri-ciri individu yang produktif adalah (1) tindakannya konstruktif; (2) percaya diri; (3) mempunyai rasa tanggungjawab; (4) memiliki rasa cinta terhadap pekerjaannya; (5) mempunyai pandangan ke depan; (6) mampu menyelesaikan persoalan; (7) dapat menyesuaikan diri dengan lingkungan yang berubah; (8) mempunyai konstribusi positif terhadap lingkungan; (9) mempunyai kekuatan untuk mewujudkan potensinya.

Sedangkan ciri pegawai yang produktif menurut Dale (1989) dalam Sedarmayanti (2000) adalah:

1. Cerdas dan dapat belajar dengan relatif cepat;

2. Kompeten secara profesional;

3. Kreatif dan inovatif;

4. Memahami pekerjaan;

5. Belajar dengan 'cerdik', menggunakan logika, efisien, tidak mudah macet dalam pekerjaan;

6. Selalu mencari perbaikan-perbaikan, tetapi tahu kapan harus terhenti;

7. Dianggap bernilai oleh atasannya;

8. Memiliki catatan prestasi yang baik;

9. Selalu meningkatkan diri.

Mengacu pada konsep tentang ciri-ciri individu dan ciri pegawai yang produktif, maka kualitas pelayanan akan memberi dampak ter- 
hadap kepuasan masyarakat sebagai subjek yang dilayani. Dimensi efektivitas dan efisiensi diletakkan pada kerangka penyelenggaraan administrasi publik. Efisien dalam pengertian memanfaatkan berbagai sumber daya yang ada, sehingga pencapaian tujuan lebih efektif, dan tepat sasaran.

\section{Kerangka Pemikiran}

Penelitian ini dilakukan pada Koperasi Warga Makmur Unit Marisa Kabupaten Pohuwato, untuk menganalisis tingkat semangat kerja karyawan berdasarkan teori Nawawi (1990), Siagian (1994) mengemukakan bahwa aspek aspek yang dinilai dalam semangat kerja mencakup sebagai berikut: 1) disiplin, 2) tanggung jawab dan kerja sama, dan 3) sedangkan untuk variabel produktivitas kerja mengacu kepada pendapat Sedarmayanti (2001: 58) bahwa produktivitas memiliki dua dimensi, yaitu dimensi efektifitas berkaitan dengan pencapaian hasil kerja yang maksimal, dalam arti pencapaian target yang berkaitan dengan kualitas, kuantitas dan waktu. Sedangkan dimensi efisiensi berkaitan dengan upaya membandingkan masukan dengan realisasi penggunaannya atau bagaimana pekerjaan tersebut dilaksanakan.

\section{Hipotesis}

Berdasarkan latar belakang dan masalah yang dikemukakan maka yang menjadi hipotesis penelitian adalah Semangat Kerja berpengaruh positif dan siknifikan terhadap Produktivitas Kerja Karyawan Pada Koprasi Warga Makmur Unit Marisa Kabupaten Pohuwato.

\section{Metode Penelitian}

Berdasarkan latar belakang penelitian dan kerangka penelitian seperti yang telah diuraikan pada bab sebelumnya, maka yang menjadi objek dari penelitian ini adalah semangat kerja terhadap produktivitas kerja karyawan pada Koprasi Warga Makmur Unit Marisa Kabupaten Pohuwato. Dalam penelitian ini penulis memilih jenis penelitian kuan- 
titatif, dengan menggunakan metode studi deskriptif /menggambarkan, yaitu metode yang diarahkan untuk memecahkan masalah dengan cara memaparkan atau menggambarkan apa adanya hasil penelitian. Ketepatan penentuan metode ini didasarkan pada pendapat Winarno Surachmad dalam Riduwan (2009: 65), bahwa aplikasi metode ini dimaksudkan untuk penyelidikan yang tertuju pada pemecahan masalah yang ada pada masa sekarang.

Pendapat sama dikemukakan oleh Nasution dalam Riduwan (2009: 65) menjelaskan bahwa penelitian deskriptif dimaksudkan untuk memberi gambaran yang lebih jelas tentang situasi-situasi sosial dengan memusatkan pada aspek-aspek tertentu dan sering menunjukkan pengaruh antara berbagai variabel. Variabel dalam penelitian ini terdiri atas dua bagian yaitu variabel independent (bebas) dan variabel dependent (terikat). Yang menjadi variabel bebas adalah semangat, sedangkan variabel terikat yaitu produktivitas. Secara jelas, maka operasionalisasi variabel penelitian ini disajikan pada tabel.1. di bawah ini:

Tabel 1

Operasionalisasi Variabel X dan Y

\begin{tabular}{|c|c|c|c|}
\hline Variabel & Dimensi & Indikator & Skala \\
\hline \multirow[b]{3}{*}{$\begin{array}{l}\text { Semangat } \\
\text { Kerja (X) }\end{array}$} & Disiplin & $\begin{array}{l}\text { a. Taat pada Peraturan } \\
\text { b. Perintah kedinasan } \\
\text { c. Peraturan jam kerja }\end{array}$ & Ordinal \\
\hline & $\begin{array}{l}\text { Tanggung } \\
\text { jawab dan } \\
\text { Kerja sama }\end{array}$ & $\begin{array}{l}\text { a. Waktu penyelesaian } \\
\text { b. Saling menghargai } \\
\text { c. Suasana dan iklim kerja yang bersahabat }\end{array}$ & Ordinal \\
\hline & $\begin{array}{c}\text { Kepuasan } \\
\text { Kerja }\end{array}$ & $\begin{array}{l}\text { a. Kepuasan di luar pekerjaan seperti } \\
\text { pendapatan, rasa, aman, dan kedudu- } \\
\text { kan yang lebih tinggi } \\
\text { b. Kepuasan terhadap pekerjaan, yaitu } \\
\text { minat kerja, peluang untuk maju, dan } \\
\text { prestise dalam organisasi } \\
\text { c. Kepuasan pribadi dan rasa bangga atas } \\
\text { profesinya. }\end{array}$ & Ordinal \\
\hline
\end{tabular}




\begin{tabular}{|c|l|l|c|}
\hline Variabel & \multicolumn{1}{|c|}{ Dimensi } & \multicolumn{1}{|c|}{ Indikator } & Skala \\
\hline & Kemampuan seseorang & 1. Kepuasan kerja & \\
& untuk menghasilkan & 2. Kuantitas kerja & \\
Produk- & barang / jasa dengan & 3. Kualitas kerja & \\
tivitas & menggunakan berba- & 4. Ketepatan waktu dalam & \multirow{2}{*}{ Ordinal } \\
kerja (Y) & gai sumber produksi & penyelesaian tugas. & \\
& sesuai dengan mutu/ & 5. Orientasi kerja & \\
& kualitas dan jangka & Kemampuan memanfaat- & \\
& waktu yang & kan perangkat yang tersedia & \\
\hline
\end{tabular}

Sumber: Sedarmayanti (2001: 58)

Dalam melakukan uji operasional dari masing-masing variabel akan diukur dengan menggunakan skala Likert. Kuesioner disusun dengan menyiapkan lima pilihan jawaban, yang masing-masing pilihan akan diberikan bobot nilai yang berbeda.

Sugiyono dalam Riduwan (2009: 54) mengatakan bahwa populasi adalah wilayah generalisasi yang terdiri obyek atau subyek yang menjadi kuantitas dan karakteristik tertentu yang ditetapkan oleh peneliti untuk dipelajari dan kemudian ditarik kesimpulannya. Dalam penelitian ini, yang menjadi populasi adalah keseluruhan karyawan Pada Koperasi Warga Makmur Unit Marisa Kabupaten Pohuwato yang berjumlah sebanyak 29 orang.

Sampel merupakan bagian dari jumlah yang dimiliki oleh populasi Sugiono (2007: 62). Karena populasinya sedikit, maka penulis mengambil semua populasi untuk dijadikan sampel dengan menggunakan metode sensus. Dalam penelitian ini, jenis data yang digunakan adalah sebagai berikut:

1. Data primer adalah data yang diperoleh dari sumber pertama baik dari individu seperti hasil wawancara maupun pengisian kuesioner yang dilakukan oleh peneliti. Data-data yang diperoleh peneliti dalam penelitian ini adalah dari daftar pertanyaanpertanyaan kuesioner yang dibagikan kepada karyawan Pada Koperasi Warga Makmur Unit Marisa Kabupaten Pohuwato. 
2. Data sekunder, merupakan data yang diperoleh berupa informasi-informasi tertulis di pada Koperasi Warga Makmur Unit Marisa Kabupaten Pohuwato yang berhubungan dan dapat mendukung dengan permasalahan dalam penelitian ini, misalnya data mengenai karyawan, tugas pokok karyawan, surat keputusan, dan lain-lain.

Dalam penulisan ini digunakan beberapa metode pengumpulan data sebagai berikut:

1. Metode kuesioner (angket), adalah metode pengumpulan data yang dilakukan dengan cara memberi seperangkat pertanyaan atau pernyataan tertulis kepada responden untuk dijawab. Daftar pertanyaan yang disusun menyangkut semangat kerja dan produktivitas kerja.

2. Metode wawancara, merupakan metode pengumpulan data melalui proses tanya jawab penulis dengan salah seorang pimpinan pada Koperasi Warga Makmur Unit Marisa Kabupaten Pohuwato yang penulis anggap bisa memberikan informasi mengenai permasalahan yang diteliti.

Untuk mendapatkan data yang baik dalam arti mendekati kenyataan (obyektif) sudah tentu diperlukan suatu instrumen atau alat pengumpul data yang baik dan lebih penting lagi adanya alat ukur yang valid dan andal (reliable). Dan untuk meyakini bahwa instrumen atau alat ukur yang valid dan andal, maka instrumen tersebut sebelum digunakan harus diuji validitas dan reliabilitasnya sehingga apabila digunakan akan menghasilkan data objektif.

Untuk mengetahui bagaimana pengaruh semangat kerja terhadap pruduktivitas kerja karyawan penulis menggunakan analisis regresi sederhana. 


\section{Pembahasan dan Analisis}

\section{Analisis Koefisien Regresi}

Penelitian ini berupaya mengkaji bagaimana hubungan kausalitas variabel semangat kerja terhadap produktivitas kerja karyawan pada Koperasi Warga Makmur Unit Marisa Kabupaten Pohuwato. Untuk itu dilakukan pengujian statistik dengan menggunakan metode analisis regresi sederhana. Selanjutnya, untuk mengetahui besarnya pengaruh semangat kerja terhadap produktivitas kerja dengan menggunakan analisis regresi sederhana maka diperoleh persamaan sebagai berikut :

$$
\mathrm{Y}=2,643+0,680 \mathrm{X}
$$

Dari hasil estimasi persamaan analisis regresi di atas dapat di interpretasikan bahwa :

$\mathrm{a}=2,643$ yang berarti bahwa produktivitas kerja konstan sebesar 2,643 jika semangat kerja di abaikan $(\mathrm{X}=0)$

bx $=0,680$ yang berarti bahwa jika semangat kerja di tingkatkan pada setiap karyawan, maka tingkat produktivitas kerja ikut meningkat sebesar 0,680 atau $68 \%$

Sedangkan untuk mengetahui apakah seangat kerja berpengaruh signifikan terhadap produktivitas kerja karyawan pada Koperasi Warga Makmur Unit Marisa Kabupaten Pohuwato, maka dilakukan uji T, seperti pada lampiran hasil pengolahan data, dimana nilai sig sebesar $0,000<$ taraf signifikansi 5\% (0.05), artinya bahwa semangat kerja berpengaruh positif dan signifikan terhada produktivitas kerja karyawan sebesar 0,569 atau $56,9 \%$.

Dengan demikian dapat disimpulkan bahwa semangat kerja berpengaruh positif dan signifikan terhadap produktivitas kerja karyawan sebesar 0,569, artinya bahwa setiap kenaikan yang terjadi pada variabel semangat kerja $(\mathrm{X})$ akan di ikuti pula oleh kenaikan variabel produktivitas kerja karyawan (Y). 


\section{Uji Model}

Hipotesis pada penelitian ini adalah terdapat pengaruh signifikan semangat kerja (X) terhadap produktivitas kerja karyawan $(\mathrm{Y})$ pada Koperasi Warga Makmur Unit Marisa Kabupaten Pohuwato. Untuk menguji apakah model regresi di atas tepat, maka dilakukan uji kesesuaian model. Uji model ini dilakukan dengan cara membandingkan antara nilai sig dengan nilai $\alpha$ pada taraf signifikansi $=0,05$. jika nilai sig $<$ nilai 0,05, maka dapat disimpulkan bahwa model di atas dapat dijelaskan oleh variasi variabel semangat kerja. Dari hasil olah data, maka dapat dilihat pada tabel Anova berikut:

Tabel 2

ANOVA

\begin{tabular}{|c|l|c|c|c|c|c|}
\hline Model & & $\begin{array}{c}\text { Sum of } \\
\text { Squares }\end{array}$ & df & $\begin{array}{c}\text { Mean } \\
\text { Square }\end{array}$ & F & Sig. \\
\hline \multirow{2}{*}{$1 \quad$ Regression } & 211,312 & 1 & 211,312 & 35,690 &, $000(\mathrm{a})$ \\
& Residual & 159,860 & 27 & 5,921 & & \\
& Total & 371,172 & 28 & & & \\
\hline
\end{tabular}

a. Predictors: (Constant), Semangat Kerja

b. Dependent Variable: Produktivitas Kerja

Sumber : Lampiran Hasil Olah Data

Dari tabel di atas menunjukkan bahwa hasil olah data statistik nilai sig $<$ nilai $\alpha=0,05$ atau $(0,000<0,05)$ artinya bahwa model di atas dapat dijelaskan oleh variasi semangat kerja, sedangkan untuk mengetahui besarnya pengaruh kontribusi model terhadap variabel terikat atau variabel Y, dapat dilihat dari besarnya koefisien determinasi (R2) seperti pada tabel Model Summay berikut : 
Tabel 3

Model Summary

\begin{tabular}{|c|c|c|c|c|}
\hline Model & R & R Square & $\begin{array}{c}\text { Adjusted } \\
\text { R Square }\end{array}$ & $\begin{array}{c}\text { Std. Error of } \\
\text { the Estimate }\end{array}$ \\
\hline 1 &, $755(\mathrm{a})$ &, 569 &, 553 & 2,43326 \\
\hline
\end{tabular}

a. Predictors: (Constant), Semangat Kerja

Sumber : Lampiran Hasil Olah Data

Dari tabel di atas dapat diinterpretasikan bahwa nilai R sebesar 0,755 ini menunjukkan bahwa terdapat hubungan korelasi positif semangat kerja dengan produktivitasi kerja karyawan sebesar 75,5\%, artinya jika semangat kerja karyawan meningkat, maka produktivitas kerja karyawan juga turut meningkat. Sedangkan nilai $\mathrm{R}$ square sebesar 0,569 atau $56,9 \%$ menunjukkan bahwa model dapat dijelaskan oleh variasi variable semangat kerja terhadap model sebesar $56,9 \%$ sedangkan sisanya sebesar $43,1 \%$ dapat dijelaskan oleh faktor-faktor lain yang tidak dimasukkan dalam model atau tidak diteliti.

\section{Penutup}

Dari pembahasan hasil penelitian di atas, maka dapat dikemukakan kesimpulan bahwa: Semangat kerja berpengaruh positif dan signifikan terhadap produktivitas kerja karyawan sebesar 0,569 (56,9\%), sedangkan 43,1\% tidak dijelaskan dalam model atau tidak diteliti. Berdasarkan kesimpulan, maka penulis dapat mengemukakan saran sebagai berikut:

1. Di sarankan kepada pihak pimpinan selaku penanggung jawab manajemen pada Koperasi Warga Makmur Unit Marisa Kabupaten Pohuwato, agar semangat kerja setiap karyawan hendaknya ditingkatkan seiring dengan tuntutan pelayanan berkualitas terhadap nasabah agar produktivitas kerja karyawan sesuai harapan Koperasi Warga Makmur Unit Marisa Kabupaten Pohuwato. 
2. Disarankan kepada kepada peneliti selanjutnya agar meneliti variabel-variabel lain yang turut mempengaruhi produktivitas kerja karyawan, misalnya pemberian tunjangan, pemberian fasilitas, sarana dan lingkungan kerja.

\section{Daítar Pustaka}

Arikunto, 2001, Metodologi Penelitian, Gramedia, Jakarta

Davis, Richard, 1996. Sukses Motivasi. PT. Gramedia, Jakarta.

Nitisemito Alex. S., 1992, Manajemen Personalia. Ghalia, Bandung. . 1992. Manajemen Personalia - Manajemen Sumber Daya Manusia. Jakarta: Ghalia

Nawawi, Hadari, 2003, Manajemen Sumberdaya Manusia, Gajahmada University Press, Yogyakarta.

Riduwan, 2009, Metode dan Tehnik Menyususn Tesis CV, Alfabeta, Bandung.

Sedarmayanti, 2001, Sumber Daya Manusia dan Produktivitas Kerja, Mardar Maju, Bandung

Sutisna wijaya, 2000, Administrasi Pendidikan, FIP, IKIP, Bandung.

Sinungan, M. 2008. Produktivitas Apa dan Bagaimana. Jakarta: Bumi Aksara

Steers, M. Richard et al. 1995. Organizational Effectiveness : A Behavioral view. Goodyear Publishing Company Inc. Santa Monica. California. United Stated of America

Wibowo, 2008. Manajemen Perubahan, Edisi Kedua, Jakarta: PT. Raja Grafindo Persada. 